\title{
Institutional Environment and Internationalization: The Case of Brazilian Agency
}

Fabricio Stocker*

School of Economics, Business and Accounting, University of São Paulo, Brazil

${ }^{*}$ Corresponding author: Stocker F, School of Economics, Business and Accounting, University of São Paulo, Brazil, Tel: +551130919411; E-mail: fabriciostocker@usp.br

Received date: March 23, 2018; Accepted date: April 12, 2018; Published date: April 19, 2018

Copyright: () 2018 Stocker F. This is an open-access article distributed under the terms of the Creative Commons Attribution License, which permits unrestricted use, distribution, and reproduction in any medium, provided the original author and source are credited.

\begin{abstract}
We analyze the acting of a formal government institution in an attempt to support business and fill the institutional void, whose context is evident in Latin America. We investigated the Brazilian Agency for Export and Investment Promotion. The data shows that the institution is configured as a structured market intermediary and directed to contribute to the institutional environment, with the shares to reduce asymmetric information, acting as a link between business exporters and importers and acting as a political strategist. However, it is evident also that the volume of companies with potential for internationalization as well as institutional settings still represent a major challenge for the institutions, being a fertile ground for future research, especially in emerging countries where institutional voids are most evident.
\end{abstract}

Keywords: Internationalization; Institutions; Emerging Economies Institutional voids

\section{Introduction}

In cycles of strong internal development, often the process of internationalization is in the background [1]. However, in a scenario of economic recession, Brazil, and other Latin American countries, seeks to sustain its position and try to develop through various ways, including the activities of internationalization of goods or capital [2]. At the organizational level, the inclusion of domestic companies in global competition instigates managers to include internationalization on the agenda of strategic discussions [3].

Research in international business should attend the environmental institutional characteristics, since these are often the key to understanding the growth and involvement of countries in internationalization processes and transaction between nations [4].

The development of institutional arrangements in most Latin American countries in recent decades is evident as an important research question, which relates the institutional environment as internationalization process [5]. In this respect, one of the possibilities that help to better understand this discussion stems from the use of the concepts of institutional theory and international business theory, which is intended to adequately understand the complex interaction between institutions and organizations in institutional settings not yet fully consolidated and rapidly changing, in addition to the literature on emerging markets has led to important research insights regarding the institutional approach [6,7].

In this sense, this study aims to analyze the institutional environment in Brazil, characterized as an emerging country, through the creation and involvement of a formal government agency, Brazilian Agency for Export and Investment Promotion, promoting the internationalization and fostering foreign investment [8]. This work is structured by this introduction; the theoretical framework which addresses the issues of internationalization and institutional environment; the methodological procedures used for research; the presentation of results and analysis of data, and finally, the final considerations.

\section{The Context of Internationalization}

With the phenomenon of globalization, the intensification of trade flows has required an increase in the organizations investments in a forward role on the international market. The internationalization of companies and increased flows of international business becomes increasingly important for countries, especially the emerging economies, due to increased global competition [3].

In Brazil, the recent process of economic liberalization, begun in the 1990s, has posed challenges and opportunities for national companies and multinationals also installed here. In previous decades, the policy of industrialization via import substitution, maintaining the relatively remote from global competition economy, making use of protection mechanisms - such as "market reserve" and the so-called "domestic content" [9]. The protectionist framework, although still in force in various sectors, has been replaced by the economic opening process.

In 2014, Brazil has appeared as the fourth country to receive foreign investment. However, it is absent from the ranking of the twenty largest exporting nations capital - FDI [10]. Thus, Brazilian companies remain on the margins of the advantages associated with a greater international integration.

The internationalization of companies, influenced by the current global economic and social situation - caused by the development of emerging countries, participation of a larger number of countries in the international market - demand business expansion and the internationalization process, benefits and advantages can be perceived by the companies, which allies the adoption of strategies, promote a competitive advantage in the market [11].

The internationalization strategies and the resulting advantages of this process lay hold of the need for a thorough analysis on the global 
market and internal organization skills. Explore new geographic markets is strongly related to the modus operandidas companies, however, the advantages and benefits of internationalization goes beyond the matter of learning and skills development, but is also related to risk reduction, expansion and international diversification, access to resources, diversification of geographic portfolio, improving the competitive position and also diversification of cash flows $[12,13]$.

The adoption of international strategies and the entry forms on the international market, can differentiate, with its own characteristics, but must be consistent with the company's organizational structure and the intended objectives in international expansion. The main strategies of internationalization and entry into foreign markets refer to exports, licensing, franchising - franchise, associations and strategic alliances, joint ventures and acquisition or installation of subsidiaries [14,15].

However, as shown Fleury and Fleury [9], the Brazilian experience, as well as most countries of emerging economies, internationalization and participation in foreign trade, concentrated in relatively few organizations, usually multinationals, classified as late entrants in foreign markets and restricting international business based on export and import. It is noteworthy the fact that the process of internationalization, based on different strategies and possibilities of action, are in an inescapable reality, still incipient in the Brazilian context.

\section{The Institutional Approach}

The design of the institutional theory was given from the new institutional school and has the function of analyzing the organizational structure in its various stakeholders in order to assess the balance of functions and dysfunctions of the structural arrangements, in this way, the process of institutionalization instrumental in creating lasting social groups [16].

Hodgson [17] says that an institution must be understood as a social organization that, through the operation of traditions, customs or legal restrictions tends to create durable and routine behavior patterns. It is this same durability and routine character in a complex world and sometimes volatile, a social science makes it possible with some practical application.

Institutions may also be responsible for structuring the interaction between agents, the definition that addresses this issue is described by Sjöstrand [18] as a kind of infrastructure that facilitates - or prevent coordination between people and the allocation of resources. The institutions then act as a kind of rationality context, emerging from human interactions and simultaneously governs. Thus, the institutions not only define and delimit the set of actions available to individuals; they are simultaneously molded by individuals and make their possible interactions [18].

For North [19] institutions are characterized as "rules of the game in a society or, more formally, (...) the restrictions devised by men who form their interaction" which directly impact on economic performance and consequently transaction costs and production. In order proposed by North, institutions can also be understood as the rule of the game, i.e., the set of standards and rules that guide, in a given environment, the actions of agents. However, in their understanding, institutions must comply with the promotion of economic growth.

At this point the settings are confused with the functions of the institutions in the social context, so Pejovich [20] affirm that "the greatest game rule function is to reduce the costs of human interaction to make more predictable behavior. To fulfill this objective, the institutions must be credible and stable "in addition to this definition North [19] points out that" his greatest function is to increase the predictability of human behavior. "

Some authors associate the institutions to the organizational decision making process, such as Knudsen [21], which says that "social institutions (...) reduce the uncertainty in the system to make the actions of more predictable agents and stabilize their expectations of what strategies the other agents may choose. "

Systematically it is possible from these concepts presented, identifying three essential elements to institutions: regularity in the actions and social interactions, their character socially constituted and their participation in the organization and order of economic processes. Thus, for purposes of this study will be adopted definition by Pondé [22] which economic institutions are regularities of behavior, social and historically constructed, shaping and order the interactions between individuals and groups of individuals, producing relatively stable patterns and certain the operation of the economic system.

The World Economic Forum recognizes the institutions the ability to interfere with the competitiveness of a nation, for borrowers that decision may define more clearly about future investments, successfully organize their production factors, define organizational strategies and have better control of the costs of these activities from the quality of the institutions that are installed within a country [23].

Thus, the institutional theory - along with other approaches, such as vision based on industry and resource-based view, for example - make up an important theoretical framework whose central theme inserts the strategy in its micro and macro analytical context [24]. That is, as well as companies, nations also differ in their strategies and overall performance in this regard, Peng et al., [25] forcefully argue that the institutions that regulate the emerging markets are mostly weak or absent.

The term "emerging markets" was coined in the early 1980, as countries with per capita income between low and medium. Later, in 1996 the international Standard and Poor's agency has published the most commonly used criteria to define the emerging markets, which contain several variables inserted into three categories: poverty, capital market and growth potential.

For purposes of this study will be used to define emerging markets by Khanna and Palepu [26] as those with the greatest amount or size "institutional voids", "these institutional voids form the 'emerging' markets and they are a major source of high costs and operational challenges of these transactions".

The absence or inefficiency of specialized intermediaries leads a country to "institutional void" because they are economic character entities strategically positioned between buyers and sellers in order to reduce transaction costs or raise the level of understanding between the parties [26].

There are mainly six types of market intermediaries: credibility promoters, which provide an independent assessment that confirms or validates the claims of the companies; consultants and information analysts who research and generate information to facilitate business decisions, aggregators and distributors, make it available to suppliers and consumers of low cost combinations and other value-added services, making use of their knowledge and economy scale, transaction facilitators who provide a platform for transactions and 
Page 3 of 6

facilitate and process of buying and selling in various markets; the referees that help market participants to resolve disputes; and regulators and policy makers, who create and reinforce the underlying rules that determine the engagement and direction of companies [26].

In this sense, this research seeks evidence on the acting of a formal government institution, where there is an incentive by state regulation, in completing and supporting the institutional void that is reportedly evident in Brazil as well as in other emerging countries in Latin America [24].

\section{Methods}

This study is qualitative and descriptive, which used a single case study. Data collection was conducted through interviews conducted in early 2016, and secondary data obtained through documents.

Because of the Brazilian Trade and Investment Promotion Agency Apex-Brasil play a unique role, being an institution with national and international representation, the work is characterized as a single case study [27]. Thus, through this only if you want to understand the reasons and its foundations on the role of Apex-Brasil in promoting the internationalization of companies.

The interview script was to guiding questions - the role of ApexBrasil as promoting the internationalization agency, the effects of the activities and actions developed by Apex-Brasil on the strategies, objectives and results of Brazilian companies; and how institutional work (at regional, national or global) is being developed by ApexBrasil to advance in the process of internationalization of Brazilian companies.

Therefore, four interviews were conducted, including the career positions as organizational structure of Apex-Brasil, as follows: Executive Director, Coordination of Corporate Management, Analyst Corporate Management and International Business Analyst, all crowded in the headquarters of the agency in Brasília - Federal District, that this research will be identified respectively as respondents $1,2,3$ and 4 .

The secondary data analyzed were obtained in the Management Report of Apex-Brasil of 2014, published in 2015, available on the website of the agency, in other national and international government sites on economic and business development. The information obtained from both surveys possible to analyze how the "institutional void" for the promotion of internationalization of Brazilian companies is completed by Apex-Brasil

The qualitative data analysis was performed using the content analysis technique proposed by Bardin [28]. This technique involves three steps: i) pre-analysis; ii) exploration of material and iii) inference and analysis. The first step involved the preparation of material, chronological organization and systematization of the initial ideas based on research problem. The second stage took place a floating reading of the documents and their categorization. The last stage includes the analysis of coding and possible inferences.

It sought to ensure the validity using multiple sources of evidence and establishing the chain of evidence in chronological order with the support of the theory. These precautions were taken during data collection stage and the analysis thereof. To increase reliability we used a research protocol, and the data were analyzed by two researchers and later confronted. This process was carried out in the data analysis stage.

\section{The Case Study}

The Brazilian Agency for Export and Investment Promotion - ApexBrasil was established in 1997 as a complementary body linked to the Brazilian Support Service for Micro and Small Enterprises - SEBRAE, with the initial objective of supporting the implementation of trade promotion policy exports Brazilian companies.

From the year 2003, Apex-Brasil was detached from SEBRAE and passed the subordination of Industry Development Ministry and Foreign Trade - MDIC, belonging to the Federal Government, the corporate constitution of private non-profit interest collective and public service.

According to the regulation of Apex-Brasil, the agency aims to "promote the implementation of export and investment promotion policies, as well as the internationalization of public and private companies, through research, training and capacity building and development institutional". The skills of Apex-Brasil aim to "commercial promotion of exports, in accordance with national development policies, particularly those relating to industrial, commercial, services and technology" [29].

Its mission is "to develop the competitiveness of Brazilian companies, promoting the internationalization of its business and attracting foreign direct investment." For this, the agency works closely with the representative bodies of the productive sectors, which are established sectoral development projects and promotion of exports, and the dissemination and strengthening of the brand and image of Brazilian companies abroad.

Apex-Brasil is bound and has a management contract with the ministry, through which the goals, objectives and responsibilities in the implementation of export promotion policies, internationalization and attraction of foreign investment are established.

Regarding the organizational structure, it is headquartered in Brasilia, the federal capital of Brazil, where are centralized administrative activities and where there is a permanent exhibition of Brazilian products for export. In addition to this headquarters, the agency is divided into 38 Operating Centers Industrial Extension Project Exporter - PEIEX installed in 13 Brazilian states.

The operational Centers - PEIEX are responsible for the basic activities of Apex-Brasil and working in training and service companies, organizational diagnosis, meetings, events, lectures, encouraging sustainable competitiveness and promoting the export culture, especially in micro, small and medium enterprises.

In addition to the units distributed in the country, Apex-Brasil also has offices and units strategies in different countries around the world. Acting as support platforms to the internationalization process of companies and as intermediaries for attracting foreign direct investment to Brazil. The international offices of the agency are located in the regions of Angola - Africa, Miami and San Francisco - in the United States, Colombia and Cuba -in Latin America, in Beijing China, Brussels - Belgium, Moscow - Russia and Dubai - United Arab Emirates, the Middle East region.

The activities carried out by Apex-Brasil focus mainly on promotion of Brazilian products and services abroad and attracting foreign investment to strategic sectors of the national economy. Acting in this way to promote the competitiveness of Brazilian companies in their internationalization processes. Table 1 describes the main actions and projects developed by Apex-Brasil in recent years. 


\begin{tabular}{|c|c|}
\hline Market intelligence & $\begin{array}{l}\text { Studies and analyzes of markets that drive companies and partners in relation to } \\
\text { the best opportunities for their international business. }\end{array}$ \\
\hline Business qualification & $\begin{array}{l}\text { Training, consulting and advisory services offered in order to increase } \\
\text { competitiveness and promote the export culture in companies, preparing them for } \\
\text { the challenges of the international market. }\end{array}$ \\
\hline Strategies for internationalization & $\begin{array}{l}\text { Set of services aimed at guiding companies and partners in defining strategies for } \\
\text { entering and advancing in the internationalization process. }\end{array}$ \\
\hline Business Promotion and Image & $\begin{array}{l}\text { Actions that aim to facilitate companies' access to international markets, diversify } \\
\text { export destinations and improve the international perception of companies, } \\
\text { Brazilian products and services. The services in this category enable entrepreneurs } \\
\text { direct contact with international business partners. }\end{array}$ \\
\hline International events & $\begin{array}{l}\text { Apex-Brasil promotes Brazilian participation in international fairs and trade } \\
\text { missions in order to offer exhibitors the opportunity to connect with buyers, opinion } \\
\text { leaders and international expert public. diversified activities during these major } \\
\text { events - tastings, exhibitions, product launches, press conferences, public relations } \\
\text { services and visual communication. }\end{array}$ \\
\hline Attracting Investments & $\begin{array}{l}\text { Actions to promote and facilitate the attraction of foreign direct investment (FDI). } \\
\text { The goal is to promote Brazil as productive capital target and capital investments } \\
\text { and facilitate the allocation of resources in the country, in addition to fostering } \\
\text { strategic partnerships and position Brazil as an attractive market. }\end{array}$ \\
\hline Competitiveness, Innovation and Sustainability & $\begin{array}{l}\text { Transversal actions to sector organizations, businesses and institutional partners of } \\
\text { the agency, with the aim of contributing to the creation of competitive advantages } \\
\text { based on sustainability and innovation. }\end{array}$ \\
\hline Sectoral interests & $\begin{array}{l}\text { Articulation with actors in the governmental sphere, support organizations and } \\
\text { business representatives in Brazil and abroad. The goal is to facilitate trade of } \\
\text { Brazilian products and services in foreign markets, as well as position the country } \\
\text { as a destination for foreign investment. }\end{array}$ \\
\hline 16). & \\
\hline
\end{tabular}

Table 1: Projects and actions developed by Apex-Brasil.

\section{Discussion and Analysis}

During the literature review, study questions which were the basis for the process of interviews and collection of secondary data were raised. The analysis of interviews and main data are presented below.

According to interview data "is part of the Apex-Brasil project, promoting knowledge and align export strategies, combining buying and selling interests between the Brazilian market with expanding markets" (Interviewee 03). This statement meets what Khanna and Palepu [26] call the information asymmetry, i.e., precarious institutional settings information asymmetry is aggravated, which can cause problems, especially with the increase in transaction costs.

Regarding the position of Apex-Brasil against the institutional environment, and the concept of market intermediaries presented by Khanna and Palepu [26], it can be said that the Apex-Brasil presents traces of a market intermediary types: consultant and information analyst, transaction facilitator and as well as regulatory and political strategist.

The agency has been working with analysis of project information and advisory activities, as the agency's actions help in the search and generates information to facilitate business decisions ahead of export activities (Interviewee 02). It also helps in the research development and customization of products and processes, seeking the satisfaction and demands of foreign markets. Also, do market research and collecting information.
Sometimes the agency acts as a transaction facilitator by providing a platform for transactions, which facilitates the process of buying and selling in different markets. This position was strengthened by the launch of the "Brazil Investment Guide" in 2014, in partnership with the Ministries of Development, Industry and Foreign Trade (MDIC), Foreign Affairs (MRE) and Agriculture, Livestock and Supply (MAPA), training and seeking investors and approach to business [30].

One can also say that the agency acts as regulatory and political strategist, because it reinforces the underlying rules that determine engagement and targeting companies, serving public interests and regional and national private. In this sense, Interviewee 01 states that, through partnerships with industry projects, "figure is also the agency as a party agent between organizations and government", supporting regulatory actions imposed by the government and strengthening development policies and promoting internationalization.

Another issue raised relates to the identification of the effects of the activities and actions developed by Apex-Brasil on the strategies, objectives and results of Brazilian companies. In this regard, the Management Report of Apex-Brasil, released in 2015, revealed that the value of export target of project participants companies was exceeded by $24.27 \%$. The value initially set at US $\$ 49.91$ billion was exceeded by the amount of US $\$ 62.02$ billion, an increase of US $\$ 15.65$ billion, $33.8 \%$ more than the total export value in the period 2013. the volume of exports of the supported companies represents $35.4 \%$ of total Brazilian industrial exports [30]. 
Page 5 of 6

This result corroborates the evidence found by Kim and Song [31] to analyze the impact of completing the institutional voids in the behavior of organizations and the increase in international business in emerging markets. With regard to foreign direct investment attraction - IED, another guiding principle of activities, according to the ApexBrasil [30], in 2014 the companies supported by the Agency announced the receipt of investments of US $\$ 4.7$ billion between productive investments and investments in participation. These investment programs are the result of outreach work and promotion through communication actions in order to reposition the image of Brazil and build a strong and distinct identity in trade promotion activities.

Another research question was to identify what type of institutional work (at regional, national or global) is being developed by ApexBrasil to advance in the process of internationalization of Brazilian companies. In this regard, all respondents say that the results obtained over the past years, with the projects and actions of Apex-Brasil, ensure that the process of internationalization of Brazilian companies, although gradually, come to structuring and receiving increasing support and evidence in the international context.

Award for export excellence, partnership with industry organizations, business mission with small and medium enterprises to countries around the world and executive training programs are some of the activities that seek to maximize and leverage the process of internationalization of companies attended (Interviewee 04).

The trade promotion - such as fairs, exhibitions, auctions, conferences, roundtables trade missions, among others - represented in $2014,89 \%$ of the shares held by the agency. According to Interviewee 01, "business events, in Brazil or abroad, are important because the entrepreneur can have access to the market, if not to close sales immediately, will be to make contacts and understand how that environment works." In the mentioned period were conducted 967 events, and 856 focused on trade promotion, 66 training events, 26 investment promotion, 11 events of international articulation and 8 events of other types.

Another project carried out by Apex-Brasil is entitled "Strategic Map of Commercial Markets and Opportunities for Brazilian Exports", which aims to support the axes of diversification of destinations for Brazilian exports and diversification of Brazilian exports [32-34]. Through this project it is possible to identify priority markets for Brazilian exports, as well as opportunities for goods and sectoral activities. The Strategic Map linked to the National Export Plan (PNE) is another of the advances and positive reinforcement of the agency as a committed organization with the positioning of Brazil as one of the major players in the international world (Interviewee 02).

\section{Conclusion}

Whereas the aim of this study was to analyze the Apex-Brasil and the internationalization process of Brazilian companies to the institutional environment in Brazil, it can be said that this is an idealized market intermediary, structured, planned and directed the assist institutional fill that emerging countries have with regard to the encouragement, promotion and training companies, especially small and medium enterprises, which aim to work or already work in international markets.

However, it appears that there is still a great challenge for the institutions, whether public or private, as well as by the Government to reduce the existing institutional gaps in emerging countries, as is the case of Brazil [31]. For, despite the performance of Apex-Brasil, the number of companies on the margins of globalization, facing bureaucratic difficulties, economic, legal, currency or resources is great. It is a universe of action by governments and other intermediary markets, in order to capture their needs, understanding their needs, provide services and solutions that include in the list of organizations entered the international market competitively.

For this reason, the recent evolution of institutional arrangements in emerging countries is an important agenda of academic research, focusing on the institutional environment and the process of internationalization. Goodstein [5] and Hinings and Greenwood [6] corroborate this statement to indicate that the investigation of the institutional theory and objective international business improve understanding of the complex interaction between institutions and organizations in poor institutional environments and rapidly changing.

As evidenced in this study, Apex-Brasil theoretically fits as a market intermediary that has three well-defined actions: reducing asymmetric information bridge between business exporters and importers and political strategist. Because it is a government agency of public interest and financed with funds from people's taxes, it is clear that its preponderant role should focus on the third type as actively participates in the regulatory process and formulation strategies that aim to insert growing Brazilian companies competitively in the international market. Therefore, its action reduces an admittedly large institutional void in emerging markets.

It is recommended for future research, explore in greater depth the impact of the actions developed by the international agencies in the practices and processes of companies, a management and focused vision for an organizational bias. It also highlights the possibility of research among the countries of Latin America in a comparative overview of the situation of the institutions created to act as intermediaries in the institutional gaps in emerging markets.

What is appearing in emerging markets is not only the prediction of their potential or the liberalization of investment environment, but also an institutional infrastructure necessary to support these economies are reorienting to the international market [26]. Ideally, as the authors express, it would be that each economy would provide a set of institutions to facilitate the functioning of markets and fill the institutional void, as is the purpose of the case presented by ApexBrasil.

\section{References}

1. Cavusgil ST, Knight G, Riesenberger JR, Rammal HG, Rose EL (2014) International business. Pearson Australia.

2. Finchelstein D (2012) Políticas públicas, disponibilidad de capital e internacionalización de empresas en América Latina: los casos de Argentina, Brasil y Chile/Public Policies, Capital Availability and Firms Internationalization in Latin America: The cases of Argentina, Brazil and Chile. Apuntes 39: 103

3. Yamakawa Y, Peng MW, Deeds DL (2008) What drives new ventures to internationalize from emerging to developed economies? Entrep Theory Pract 32: 59-82.

4. Henisz W, Swaminathan A (2008) Institutions and international business. Journal of International Business Studies 39: 537-539.

5. Goodstein J (2015) Philip Selznick and the problems of organizational integrity and responsibility. Research in the Sociology of Organizations 44: 175-197. 
Citation: Stocker F (2018) Institutional Environment and Internationalization: The Case of Brazilian Agency . Bus Eco J 9: 349. doi: 10.4172/2151-6219.1000349

Page 6 of 6

6. Hinings CR, Greenwood R (2015) Missing in action: The further contribution of Philip Selznick to contemporary institutional theory. Emerald Group Publishing Limited, pp: 121-148.

7. Van Hoorn A, Maseland R (2016) How institutions matter for international business: Institutional distance effects vs institutional profile effects. Journal of International Business Studies 47: 374-381.

8. Apex-Brasil (2016) Agência Brasileira de Promoção de Exportações e Investimentos.

9. Fleury A, Fleury MTL (2012) Multinacionais brasileiras: competências para a internacionalização.

10. UNCTAD (2014) World Investment Report 2014.

11. Johanson J, Vahlne JE (2009) The Uppsala internationalization process model revisited: From liability of foreignness to liability of outsidership. Journal of international business studies 40: 1411-1431.

12. Deresky H (2000) International management: Managing across borders and cultures. Pearson Education India.

13. Peng MW (2013) Global strategy. Cengage learning.

14. Root FR (1994) Entry strategies for international markets. Jossey-Bass.

15. Hitt MA, Ireland RD, Hoskisson RE (2012) Strategic management cases: competitiveness and globalization. Cengage Learning.

16. Tolbert PS, Zucker LG (1999) The institutionalization of institutional theory. Studying Organization. Theory \& Method, pp: 169-184.

17. Hodgson GM (1988) Economics and institutions. In Journal of Economic Issues.

18. Sjöstrand SE (1995) Towards a theory of institutional change. Economic institutions: Theory and Applications, pp: 19-44.

19. North DC (1993) Institutions, institutional change and economic performance. Economics Development and Cultural Change.

20. Pejovich S (2012) Economic analysis of institutions and systems. International Studies in Economics and Econometrics.

21. Knudsen C (1993) Modelling Rationality. Institutions and Process in Economic Theory, pp: 265-299.
22. Pondé JL (2005) Instituições e mudança institucional: uma abordagem schumpeteriana. Revista Economia 6: 119-160.

23. Schwab K, Sala-i-Martin X (2011) The global competitiveness report 2011-2012. Geneva: World Economic Forum.

24. Stephan U, Uhlaner LM, Stride C (2015) Institutions and social entrepreneurship: The role of institutional voids, institutional support, and institutional configurations. Journal of International Business Studies 46: 308-331.

25. Peng MW, Wang DY, Jiang Y (2008) An institution-based view of international business strategy: A focus on emerging economies. Journal of International Business Studies 39: 920-936.

26. Khanna T, Palepu K (2010) Winning in the emerging economies: A road map for strategy and execution. Harvard Business Press, pp: 174-180.

27. Yin RK (2013) Case study research: Design and methods. Sage publications.

28. Bardin L (2006) Content Analysis. Lisbon: Editions.

29. MDIC (2016) Ministério do Desenvolvimento, Indústria e Comércio Exterior. Governo Federal do Brasil.

30. Apex-Brasil (2016) Relatório de Gestão da Agência Brasileira de Promoção de Exportações e Investimentos .

31. Kim H, Song J (2017) Filling institutional voids in emerging economies: The impact of capital market development and business groups on M\&A deal abandonment. Journal of International Business Studies 48: 308-323.

32. Finchelstein D (2009) Different states, different internationalizations: a comparative analysis of the process of firms' internationalization in Latin America. In 28th Lasa International Congress, Rio de Janeiro.

33. Langlois RN, Robertson PL (2002) Firms, markets and economic change: A dynamic theory of business institutions. Routledge.

34. Rutherford M (2001) Institutional economics: then and now. Journal Econ Perspect 15: 173-194. 